\title{
PERBANDINGAN EKSTRAK LAMUR Aquilaria malaccensis DENGAN METODE MASERASI DAN REFLUKS
}

\author{
Eka Siswanto Syamsul ${ }^{1}$, Nadhila Ajrina Amanda ${ }^{2}$, Dwi Lestari ${ }^{3}$ \\ ${ }^{1,2}$ STIKES Samarinda \\ ${ }^{3}$ Universitas Muhammadiyah Kalimantan Timur \\ Email korespondensi : eka8382@gmail.com
}

\begin{abstract}
ABSTRAK
Gaharu (Aquilaria malaccensis Lamk) adalah tanaman dari keluarga thymelaeaceae yang banyak digunakan oleh masyarakat Kabupaten Kutai Barat sebagai tanaman obat untuk luka kulit, diabetes, asma, sakit perut dan gangguan tidur, aromaterapi dan digunakan sebagai bahan untuk parfum karena ini memiliki aroma yang khas. Proses ekstraksi akan menentukan berapa banyak hasil yang dihasilkan. Penelitian ini bertujuan untuk mengetahui persentase (\%) hasil ekstrak etanol daun gaharu menggunakan metode maserasi dan refluks. Tahap penelitian meliputi penentuan tanaman, pemrosesan sampel, ekstraksi menggunakan metode maserasi dan refluks dengan pelarut etanol $70 \%$, penentuan hasil dan penyaringan fitokimia. Analisis data dalam bentuk analisis data deskriptif dan disajikan dalam bentuk tabel. Hasil penelitian menunjukkan bahwa metode refluks menghasilkan rendemen rata-rata yang lebih tinggi 30,70\% dan metode maserasi 29,97\%. Hasil uji statistik menggunakan metode Independent Sample T-Test menunjukkan bahwa tidak ada perbedaan yang signifikan dalam hasil yang dihasilkan dari metode maserasi dan refluks karena ( $p>0,05)$. Hasil uji skrining fitokimia menunjukkan bahwa ekstrak daun gaharu mengandung flavonoid, tanin, saponin dan steroid
\end{abstract}

Kata kunci: Aquilaria malaccensis Lamk, metode maserasi dan refluks, rendemen 


\title{
COMPARISON OF Aquilaria malaccensis LAMK EXTRACT WITH MASERATION AND REFLUX METHODS
}

\begin{abstract}
Gaharu (Aquilaria malaccensis Lamk) is a plant of the thymelaeaceae family that is widely used by the people of West Kutai Regency as a medicinal plant for skin wounds, diabetes, asthma, stomach pain and sleep disorders, aromatherapy and used as ingredients for perfume because it has a distinctive aroma. The extraction process will determine how much yield is produced. This study aims to determine the percent (\%) yield of agarwood leaf ethanol extract using maceration and reflux methods. The research stage includes plant determination, sample processing, extraction using maceration and reflux methods with $70 \%$ ethanol solvent, determination of the yield and phytochemical screening. Data analysis in the form of descriptive data analysis and presented in tabular form. The results showed that the reflux method produced a higher average yield of $30.70 \%$ and maceration method of 29.97\%. Statistical test results using the Independent Sample T-Test method showed that there was no significant difference in the yield produced from the maceration and reflux method because ( $p>0.05)$. Phytochemical screening test results showed that agarwood leaf extract contains flavonoids, tannins, saponins and steroids
\end{abstract}

Keywords: Aquilaria malaccensis Lamk, maceration and reflux method, yield

\section{PENDAHULUAN}

Di Papua masyarakat menggunakan daun, kulit dan akar gaharu sebagai pengobatan untuk penyakit malaria dan perawatan kulit (Sumarna, 2002). Secara empiris masyarakat di Kalimantan Timur khususnya Kampung Empas Kecamatan Melak Kabupaten Kutai Barat menggunakan daun dan batang gaharu sebagai pengobatan untuk luka pada kulit, diabetes, asma, sakit perut dan gangguan tidur. Pengobatan dilakukan dengan cara meminum rebusan daun dan menghirup aroma batang gaharu yang dibakar.

Pemilihan metode penelitian dalam proses pemisahan senyawa aktif merupakan aspek yang sangat penting untuk diperhatikan karena proses pemisahan akan menentukan seberapa besar rendemen yang dihasilkan. Rendemen menggunakan satuan persen (\%), semakin tinggi nilai rendemen yang dihasilkan menandakan nilai ekstrak yang didapat semakin banyak (Armando, 2009). Rendemen dapat mempengaruhi suatu ekstrak yang disebabkan oleh beberapa faktor salah satunya metode ekstraksi yang digunakan. Metode ekstraksi terdiri atas ekstraksi cara dingin meliputi maserasi, perkolasi dan ekstraksi cara panas meliputi sokhletasi, refluks, dekok, infus dan digesti (DepKes RI, 2000).

Ekstraksi merupakan proses pemisahan senyawa dari simplisia dengan 
menggunakan pelarut yang sesuai. Metode pemisahan ekstraksi menggunakan prinsip kelarutan like dissolve like dimana suatu pelarut polar akan melarutkan senyawa polar dan pelarut non polar akan melarutkan senyawa non polar (Kiswandono, 2011). Tujuan ekstraksi yaitu untuk menarik atau memisahkan senyawa dari simplisia atau campurannya. Pemilihan metode dilakukan dengan memperhatikan senyawa, pelarut yang digunakan serta alat yang tersedia. Metode ekstraksi yang umum digunakan adalah maserasi dan refluks (Hanani, 2017). Berdasarkan penelitian Khalil dkk (2013), daun gaharu (Aquilaria malaccensis Lamk) memiliki beberapa kandungan yang diperoleh dari skrining fitokimia antara lain alkaloid, flavonoid, tanin, saponin, dan triterpenoid atau steroid.

\section{METODE PENELITIAN}

Penelitian ini merupakan penelitian Eksperimental yang dilakukan di Laboratorium Fitokimia dan Farmakologi Sekolah Tinggi Ilmu Kesehatan Samarinda (STIKSAM). Penelitian ini dilakukan untuk mengetahui perbandingan rendemen ekstrak daun gaharu (Aquilaria malaccensis Lamk) dengan metode maserasi dan refluks. Tahapan penelitian ini dimulai dengan pengumpulan sampel, determinasi tumbuhan, pengolahan sampel, proses ekstraksi, penetapan rendemen, dan skrining fitokimia.

Alat yang digunakan dalam penelitian ini adalah rotary evaporator $\left(\right.$ IKA $\left.^{\circledR}\right)$, Oven $\left(\right.$ Memmert $\left.^{\circledR}\right)$, maserator $\left(\mathrm{IKA}^{\circledR}\right)$, penangas air, pengaduk elektrik, blender, mikropipet $\left(\mathrm{Vitlab}^{\circledR}\right)$, timbangan analitik $\left(\right.$ Ohaus $\left.^{\circledR}\right)$, ayakan mesh 60, seperangkat alat gelas $\left(\right.$ pyrex $\left.^{\circledR}\right)$, corong buchner, rak tabung reaksi, cawan porselen, penjepit tabung, spatel logam, tolples kaca, dan botol semprot.

Bahan yang digunakan dalam penelitian ini adalah daun gaharu, etanol $70 \%$, pereaksi bouchardat, pereaksi mayer, pereaksi dragendorf, asam klorida $2 \mathrm{~N}$, asam klorida pekat, besi (III) klorida $1 \%$, amil alkohol, serbuk magnesium, nheksan, asam sulfat pekat, dan asam asetat anhidrat.

\section{Prosedur Penelitian}

a. Pengumpulan sampel

Sampel yang digunakan adalah daun gaharu tua yang diambil dari Kampung Empas Kabupaten Kutai Barat.

b. Determinasi Tumbuhan

Determinasi tumbuhan dilakukan untuk mengetahui kebenaran sampel. Identifikasi dilakukan di Laboratorium Anatomi dan Sistematika Tumbuhan Fakultas Matematika dan Ilmu Pengetahuan Alam (F-MIPA) Universitas Mulawarman.

c. Pengolahan Sampel

Dilakukan pengumpulan sampel yang diambil dari Kampung Empas Kabupaten Kutai Barat, kemudian dilakukan sortasi basah untuk memisahkan daun dari kotoran atau benda asing. Daun gaharu selanjutnya dicuci dengan air mengalir dan kemudian dilakukan pengeringan dengan cara diangin-anginkan di atas nampan tanpa paparan sinar matahari lalu disortasi kering yang bertujuan untuk memisahkan kembali kotoran yang masih menempel pada daun. Simplisia yang telah kering kemudian dihaluskan menggunakan blender. 
d. Susut Pengeringan

Rumus Susut Pengeringan

$\%$ Susut Pengeringan $=$

$\frac{\text { berat basah-berat kering }}{\text { berat basah }} \times 100 \%$

e. Proses Ekstraksi

1) Maserasi

Ditimbang serbuk simplisia daun gaharu sebanyak 25 gram, dimasukkan kedalam bejana kaca tambahkan dengan pelarut etanol $70 \%$ sebanyak $250 \mathrm{ml}$. Simplisia diaduk selama 2 jam dengan menggunakan maserator kemudian didiamkan selama $1 \times 22$ jam pada suhu ruangan dan terhindar dari cahaya, disaring filtrat dengan menggunakan corong buchner. Ekstrak cair yang diperoleh diuapkan diatas penangas air hingga didapatkan ekstrak yang kental. Dilakukan replikasi sebanyak 3 kali.

2) Refluks

Ditimbang serbuk simplisia daun gaharu sebanyak 25 gram, dimasukkan kedalam labu alas bulat ditambahkan dengan pelarut etanol $70 \%$ sebanyak 250 $\mathrm{ml}$ kemudian dipanaskan pada suhu $60^{\circ} \mathrm{C}$ selama 3 jam, lalu disaring menggunakan corong buchner. Ekstrak cair yang diperoleh diuapkan diatas penangas air hingga didapatkan ekstrak yang kental. Dilakukan replikasi sebanyak 3 kali.

f. Perhitungan Rendemen

Rumus perhitungan rendemen

$\%$ Rendemen =

$\frac{\text { bobot ekstrak yang diperoleh }(\mathrm{gram})}{\text { bobot simplisia sebelum diekstraksi (gram) }} \times$ $100 \%$

g. Penetapan Kadar Air

Ekstrak kental daun gaharu ditimbang sebanyak 2 gram dimasukkan ke dalam cawan porselen yang telah ditimbang, lalu dipanaskan pada suhu $105^{\circ} \mathrm{C}$ selama 30 menit, kemudian didinginkan dalam desikator dan ditimbang. Diulangi sampai mendapatkan bobot tetap (Supomo, 2016)

Rumus perhitungan kadar air (Andarwulan, 2016)

$$
\text { Kadar air }=\frac{b-(c-a)}{b} \times 100 \%
$$

Keterangan: $a=$ Berat cawan

$b=$ Berat sampel

$c=$ Berat cawan + sampel

Dilakukan strining Fitokimia dengan cara ditimbang ekstrak sebanyak 0,5 gram lalu dilarutkan dengan etanol $70 \%$ sebanyak $10 \mathrm{ml}$ kemudian ditambahkan aquades hingga $100 \mathrm{ml}$, selanjutnya larutan ekstrak digunakan untuk uji Alkaloid, Flavonoid, Tanin, Saponin dan Steroid.

\section{Analisis Data}

Analisis data pada penelitian ini adalah berupa analisis data dekstriptif berupa hasil \% rendemen ekstrak etanol daun gaharu yang diekstraksi menggunakan metode maserasi dan refluks. Kemudian data yang diperoleh disajikan dalam bentuk tabel.

\section{HASIL DAN PEMBAHASAN}

Tabel 1. Hasil Rendemen Ekstrak Daun Gaharu

\begin{tabular}{clcc}
\hline No. & $\begin{array}{c}\text { Metode } \\
\text { Ekstraksi }\end{array}$ & $\begin{array}{c}\text { Rendemen } \\
(\boldsymbol{\%})\end{array}$ & $\begin{array}{c}\text { Rata- } \\
\text { Rata } \\
\text { Rendeme } \\
\mathbf{n}(\boldsymbol{\%})\end{array}$ \\
\hline \multirow{2}{*}{1} & Maserasi I & 30,00 & \\
& Maserasi II & 29,56 & 29,97 \\
& Maserasi III & 30,36 & \\
2 & Refluks I & 30,56 & \\
& Refluks II & 30,52 & 30,70 \\
& Refluks III & 31,04 & \\
\hline
\end{tabular}

Tabel 1. terdapat perbedaan hasil dari rendemen ekstrak dari dua metode 
ekstraksi yang digunakan. Hal tersebut membuktikan bahwa metode ekstraksi cara dingin (maserasi) dan cara panas (refluks) berpengaruh terhadap hasil rendemen yang diperoleh. Metode refluks menghasilkan nilai rendemen ekstrak lebih tinggi $(30,70 \%)$ terhadap maserasi $(29,97 \%)$.

Metode maserasi menghasilkan rendemen ekstrak yang lebih rendah dibandingkan metode refluks, karena metode ini tidak menggunakan bantuan pemanasan maka untuk menarik senyawa yang lebih maksimal dibutuhkan pula waktu dan lamanya proses ekstraksi. Semakin lama waktu dan semakin tinggi suhu ekstraksi, rendemen yang dihasilkan semakin besar. Apabila suhu dan waktu ekstraksi terlalu tinggi dapat menyebabkan perusakan terhadap senyawa-senyawa yang terdapat dalam simplisia (Budiyanto, 2008; Syamsul, dan Purwanto, 2014). Hasil uji SPSS dengan Independent Sample T-Test menunjukkan bahwa nilai $(p>0,05)$ yang artinya tidak terdapat perbedaan yang signifikan terhadap rendemen yang dihasilkan menggunakan metode maserasi dan metode refluks. Hal ini bisa dipengaruhi oleh faktor ukuran partikel simplisia, karena pada proses pengolahan simplisia tidak dilakukan pengayakan dengan mesh 60. Antari dkk (2015) menyatakan semakin halus bahan yang digunakan, maka semakin luas bidang kontak antara bahan dengan pelarut sampai pada batas senyawa yang diesktrak habis dalam bahan.

\section{A. Skrining Fitokimia Ekstrak Daun Gaharu}

Skrining fitokimia dilakukan untuk mengetahui golongan senyawa yang terdapat dalam ekstrak etanol $70 \%$ daun gaharu. Golongan senyawa yang diidentifikasi yaitu alkaloid, flavonoid, tanin, saponin, dan steroid. Proses skrining fitokimia dilakukan dengan mengambil sebagian ekstrak dari maserasi dan refluks untuk diketahui golongan senyawa metabolit sekundernya. Hasil uji skrining ekstrak yang dihasilkan dari metode maserasi positif mengandung senyawa flavonoid, tanin, saponin dan steroid, sedangkan untuk alkaloid hasilnya negatif. Kemudian ekstrak dari metode refluks positif mengandung senyawa flavonoid dan saponin, sedangkan senyawa alkaloid, tanin dan steroid hasilnya negatif. Hal ini sesuai dengan penelitian Silaban, 2015 bahwa ekstrak etanol daun gaharu tidak mengandung senyawa alkaloid. Hasil skrining fitokimia ekstrak daun gaharu (Aquilaria malaccensis Lamk) dapat dilihat pada Tabel 2.

\begin{tabular}{|c|c|c|c|c|}
\hline \multirow{2}{*}{ No. } & \multirow{2}{*}{$\begin{array}{c}\text { Golonga } \\
\mathbf{n}\end{array}$} & \multirow{2}{*}{ Pereaksi } & \multicolumn{2}{|c|}{$\begin{array}{c}\text { Hasil Skrining } \\
\text { Fitokimia }\end{array}$} \\
\hline & & & $\begin{array}{c}\text { Mase } \\
\text { rasi }\end{array}$ & Refluks \\
\hline \multirow{3}{*}{1.} & \multirow{3}{*}{ Alkaloid } & Dragendorf & - & - \\
\hline & & Mayer & - & - \\
\hline & & Bouchardat & + & + \\
\hline 2. & $\begin{array}{l}\text { Flavonoi } \\
\mathrm{d}\end{array}$ & $\begin{array}{l}\text { Serbuk Mg, } \\
\mathrm{HCl} \text { pekat, } \\
\text { Amil } \\
\text { Alkohol }\end{array}$ & + & + \\
\hline 3. & Tanin & $\mathrm{FeCl}_{3} 1 \%$ & + & - \\
\hline 4. & Saponin & $\mathrm{HCl} 2 \mathrm{~N}$ & + & + \\
\hline 5. & Steroid & $\begin{array}{l}\text { N-Heksan, } \\
\text { Asam } \\
\text { Asetat } \\
\text { Anhidrat, } \\
\mathrm{H}_{2} \mathrm{SO}_{4} \\
\text { Pekat }\end{array}$ & + & - \\
\hline
\end{tabular}

Tabel 2. Hasil Skrining Fitokimia Ekstrak Daun Gaharu

Keterangan:

-Tidak mengandung metabolit

+ mengandung metabolit 
Pengujian ekstrak daun gaharu (Aquilaria malaccensis Lamk) menunjukkan kandungan senyawa flavonoid karena pada saat penambahan pereaksi terbentuk warna kuning pada lapisan amil alkohol.

Tanin merupakan bagian dari senyawa fenolik. Tanin ditunjukkan dari adanya perubahan warna menjadi hijau kehitaman setelah penambahan pereaksi $\mathrm{FeCl}_{3}$ yang bereaksi dengan salah satu gugus hidroksil pada senyawa tanin (Astarina dk, 2013). Hasil penelitian menunjukkan ekstrak yang didapat dari hasil maserasi positif mengandung senyawa tanin, sedangkan ekstrak hasil refluks tidak mengandung senyawa tanin. Menurut penelitian Karina, dkk (2016) dan Syamsul dkk (2016) menyatakan bahwa proses ekstraksi yang terlalu lamaB akan menyebabkan larutnya zat-zat non tanin yang berdampak pada rusaknya kandungan tanin. Senyawa aktif seperti tanin akan mengalami perubahan struktur dengan suhu diatas $50^{\circ} \mathrm{C}$ sehingga senyawa aktif tersebut rusak oleh pemanasan yang tinggi (Yuliantari dkk,2017). Yusro (2013) menyatakan bahwa lama pemanasan 2 jam akan menghasilkan kadar tanin aktif yang tinggi, namun dengan semakin lamanya pemanasan kadar tanin aktif akan semakin menurun dan jauh dari kadar tanin pada awal pemanasan.

Saponin merupakan golongan dari senyawa glikosida yang mempunyai struktur steroid yang dapat membentuk larutan koloidal dalam air dan membentuk buih/busa bila dikocok (Harborne, 1987). Hasil uji skrining dari ekstrak maserasi dan refluks membentuk buih ketika dikocok yang artinya mengandung senyawa saponin.

Senyawa steroid terdapat dalam sel tumbuhan dalam sitoplasma. Secara kimia, pembentukan steroid adalah kolesterol yang bersifat non polar sehingga dapat larut dalam lemak. Berdasarkan hasil uji skrining, ekstrak dari metode maserasi positif memiliki senyawa steroid dengan terjadinya perubahan warna menjadi biru kehijauan setelah ditetesi asam asetat anhidrat dan asam sulfat pekat, sedangkan ekstrak dari metode refluks senyawa steroid hilang. Semakin lama waktu dan tingginya suhu pada saat proses ekstraksi akan menyebabkan senyawa aktif pada ekstrak akan rusak (Emilda, 2008).

\section{Penetapan Kadar Air Ekstrak Daun Gaharu}

Penetapan kadar air merupakan persyaratan yang harus dipenuhi dalam standarisasi tumbuhan yang berkhasiat obat dengan tujuan memberikan rentang tentang besarnya senyawa yang hilang pada proses pengeringan (DepKes RI, 2000). Menurut penelitian Najib, dkk (2017) menyatakan penetapan kadar air ini dilakukan pengukuran sisa zat setelah proses pengeringan pada suhu $105^{\circ} \mathrm{C}$ selama 30 menit. Pada suhu $105^{\circ} \mathrm{C}$ air akan menguap dan senyawa-senyawa yang mempunyai titik didih yang lebih rendah dari air akan ikut menguap pula.

Berdasarkan hasil penetapan kadar air yang diperoleh dari ekstrak daun gaharu (Aquilaria malaccensis Lamk) adalah sebagai berikut. 
Tabel. 3 Hasil Penetapan Kadar Air Ekstrak Daun Gaharu

\begin{tabular}{clcc}
\hline No. & $\begin{array}{c}\text { Metode } \\
\text { Ekstraksi }\end{array}$ & $\begin{array}{c}\text { Kadar Air } \\
(\boldsymbol{\%})\end{array}$ & $\begin{array}{c}\text { Rata-Rata } \\
\text { Kadar Air } \\
(\%)\end{array}$ \\
\hline \multirow{2}{*}{1} & Maserasi I & 18 & \\
& Maserasi II & 19,5 & 19,33 \\
& Maserasi III & 20,5 & \\
\multirow{2}{*}{2} & Refluks I & 19,5 & \\
& Refluks II & 19 & 19,5 \\
& Refluks III & 20 & \\
\hline
\end{tabular}

Hasil penetapan kadar air yang diperoleh dari ekstrak kental dari metode maserasi sebesar $19,33 \%$ dan dari metode reluks sebesar $19,5 \%$. Hasil dari kedua metode tersebut dapat diartikan bahwa ekstrak yang diperoleh termasuk ekstrak kental dengan range 5-30\%, hal ini telah memenuhi persyaratan yang telah ditetapkan (Voight, 1995).

\section{SIMPULAN}

Berdasarkan hasil penelitian yang telah diperoleh, metode maserasi menghasilkan rata-rata rendemen sebesar 29,97\% dan metode refluks menghasilkan rata-rata rendemen sebesar 30,70\%. Hasil uji statistika menunjukkan ( $\mathrm{p}>0,05$ ) tidak terdapat perbedaan yang signifikan terhadap rendemen yang dihasilkan.

\section{UCAPAN TERIMAKASIH}

Terimakasih kepada STIKES Samarinda dan Universitas Muhammadiah Kalimantan Timur (UMKT) yang telah mendanai penelitian ini

\section{DAFTAR PUSTAKA}

Armando, R. 2009. Memproduksi 15 Minyak Atsiri Berkualitas. Jakarta: Penerbit Penebar Swadaya. Hal: 71

Astarina, N.W.G., Astuti, K.W., dan Warditiani, N.K. 2013. "Skrining
Fitokimia Ekstrak Metanol Rimpang Bangle". Jurnal Farmasi Udayana Vol.2, No.4:1-7

Budiyanto, A dan Yulianingsih. 2008. "Pengaruh Suhu dan Waktu Ekstraksi Terhadap Karakter Pektin dari Ampas Jeruk Siam” Jurnal Pascapanen 5(2):3244

Departemen Kesehatan RI. 2000. Parameter Standar Umum Ekstrak Tumbuhan Obat. Cetakan Pertama. Jakarta: DepKes RI: Hal 5, 11, 14

Emilda. 2008. "Pemanfaatan Steroid Asal Jeroan Teripang Sebagai Bahan Aktif Dalam Sex Reversal Pada Ikan Gapi”. Tesis. Bogor: Institut Pertanian Bogor

Hanani, E. 2017. Analisis Fitokimia. Jakarta: Penerbit Buku Kedokteran EGC: Hal 9, 79, 103, 133, 191, 227

Harborne, J.B. 1987. Metode Fitokimia. Bandung. Terbitan Kedua. Bandung: Penerbit ITB: Hal 236

Karina, Indrayani, Y., dan Sirait, S.M. 2016. "Kadar Tanin Biji Pinang (Areca catechu L.) Berdasarkan Lama Pemanasan dan Ukuran Serbuk". Jurnal Hutan Lestari. Vol.4, No.1 : 119-127

Khalil, A.S., Rahim, A.A., Taha, K.K., Abdallah,K.B. 2013. "Characterization of Methanolic Extracts of Agarwood Leaves". Journal of Applied and Industrial Sciences, 1(3): 78-88

Kiswandono, A.G. 2011. "Skrining Senyawa Kimia dan Pengaruh Metode 
Maserasi dan Refluks Pada Biji Kelor (Moringa oleifera Lamk) Terhadap Rendemen Ekstrak Yang Dihasilkan". Jurnal Sains Natural Universitas Nusa Bangsa. Vol. 1, No. 2, Juli 2011, 126 134

Najib,A., $\quad$ Malik,A., $\quad$ Ahmad,A.R., Handayani,V., Syarif,R.A., dan Waris,A. 2017. "Standardisasi Ekstrak Air Daun Jati Belanda dan Teh Hijau". Jurnal Fitofarmaka Indonesia Vol.4 No. 2

Silaban, S.F. 2015. "Skrining Fitokimia dan Uji Aktivitas Antioksidan Ekstrak Etanol Daun Gaharu (Aquilaria malaccensis Lamk)". Skripsi. Sumatera Utara: Fakultas Farmasi Universitas Sumatera Utara

Sirait, M. 2007. Penuntun Fitokimia Dalam Farmasi. Bandung: Penerbit ITB

Sumarna, Y. 2002. Budidaya Gaharu. Jakarta: Penerbit Swadaya

Supomo., Risa, S., dan Risaldi, J. 2016.

"Karakterisasi dan Skrining Fitokimia Daun Kerehau (Callicarpa longifolia Lamk.)". Jurnal Kimia Mulawarman Vol.13 No.2

Susanty dan Bachmid, F. 2016. "Perbandingan Metode Ekstraksi Maserasi dan Refluks Terhadap Kadar Fenolik dari Ekstrak Tongkol Jagung (Zea mays L)". Jurnal Konversi Vol.5 no.2.

Syamsul, E.S, dan Purwanto, E.N, 2014, Uji aktivitas perasan buah mentimun
(Cucumis sativus L) sebagai biolarvasida terhadap larva nyamuk Aedes aegypti L, Jurnal Kimia Universitas Mulawarman.

Syamsul, E.S, Andani, F, Soemarie, Y.B. 2016, Uji Aktivitas analgetik ekstrak etanolik daun kerehau (Collicarpa longifolia Lamk.) pada mencit putih, Traditional Medicine Journal

Yuliantari,N.W.A., Widarta,I.W.R., dan Permana,I.D.G.M. 2017. "Pengaruh Suhu dan Waktu Ekstraksi Terhadap Kandungan Flavonoid dan Aktivitas Antioksidan Daun Sirsak (Annona muricata L.) Menggunakan Ultrasonik". Jurnal Media Ilmiah Teknologi Pangan. Vol.4, No.1 : 35-42

Yusro,F. 2013. "Kadar Tanin Aktif Ekstrak Kulit Kayu Jengkol (Pithecolobium jiringa Jack) dan Kereaktifannya Terhadap Formaldehid". Jurnal Vokasi. Vol. 9, No.1 : 21-26 